\title{
Bank soundness: A PLS-SEM approach
}

Charmele Ayadurai, Rasol Eskandari ${ }^{1}$

\begin{abstract}
During the Global Financial Crisis (GFC) of 2007-09, even banks in industrial economies with long established markets suffered significantly. This highlights the weakness in the banking system and the importance of a sound banking sector. This article illustrates the drivers of bank soundness for G7 countries during the period 2003-2013. In creating a parsimonious model, the study assembles 18 manifest variables of 6 constructs as the cause of bank soundness. The structural equation model comprises of six latent exogenous constructs [Capital (C), Asset (A), Management (M), Earnings (E), Liquidity (L) and Sensitivity(S)] which explains the observed consequences of bank soundness in these countries. Results indicate that $43.8 \%$ of the variation in banks' soundness is explained by CAMELS. The model's predictive relevance $\left(\mathrm{Q}^{2}\right)$ with regard to endogenous construct stands at a strong category of 0.425 . The results imply that banks placed high importance on off balance sheet and capital activities thus taking on higher risk. Surprisingly, these banks were operating at low levels of capital and liquidity resembling banks that failed during the Great Depression. The weakness in capital and liquidity measures calls for robust policy measures to create convergence with soundness.
\end{abstract}

Keywords

Bank soundness; G7; CAMELS; Financial Crisis

\footnotetext{
1 Charmele Ayadurai (‥Ayadurai@edu.salford.ac.uk)

Rasol Eskandari (R.Eskandari@salford.ac.uk)

University of Salford, Salford Business School
} 


\section{Introduction}

The recent GFC resulted in large bank failures in the G7 countries (Canada, France, Germany, Italy, Japan, UK and US) with the exception of Canada, which led to deep recessions. This highlights the chronic weakness in the existing banking sector and the importance of a robust banking system. A sound banking system has to be efficient in the key role it plays to influence the economy positively.

This article assesses the soundness of banks in G7 countries, to better understand the workings of these banks as providers of payment services and hubs for economic and financial activities especially during the crisis period. The motivation to study the G7 banks lies on several reasons. G7 countries are among the top 10 biggest economies, 5 of the countries hold the top 10 financial hub position in the world and G7 countries play a key role in global monetary affairs and trade. As a result, these countries hold a significant position in influencing the world economy at large.

In assessing the soundness of banks, seven clusters of financial indicators and credit rating models were considered, namely, Financial Soundness Indicator (FSI), Basel Core Principles (BCP), CAMELS, Moody, Fitch, Standard and Poor (S\&P) and Bank Financial Strength Rating (BFSR). The study puts together 60 bank-level variables from these indicators and applied stock returns as the proxy for bank soundness. Partial least square structural equation modeling was applied to assess the banks.

The study offers two main contributions. First, the assessment of G7 banks as key players in global trade and monetary affairs during the GFC. Second contribution is to apply seven sets of bank soundness and credit rating indicators in the assessment.

\section{Literature review}


Bank soundness is a concept that signifies the ability of a bank to survive an adversity in the economy (Lindgren et al.1996). Financial ratios play a key role in assessing bank soundness as early signs of impairment could be easily detected by the changes in the internal condition of the banks (Sinkey 1979; Hanc 1998). Several measures have been suggested for bank soundness such as earnings (Gasbarro et. al. 2002); capital (Schaeck and Čihák 2007); internal governance (Lindgren et al.1996) and credit ratings (Podviezko and Ginevičius 2010; Demirgüç-Kunt and Detragiache 2011). A sound bank is also viewed as a bank that is solvent and remains solvent. The future solvency of a bank depends on its efficiency and thus its profitability. Therefore, solvency is a measure of the positive net worth of a bank.

As banks go through different phases, it's impossible to precisely classify banks as "sound" or "unsound" at a given point of time. This is because banks could be performing well at the moment but show signs of probable problems in the future. As theory is unable to provide a clear answer on what constitutes a sound bank, the study looks to bank specific sets of indicators for solutions.

In literature as reported by Bernanke (2007) the Fed examines the safety and soundness of banks in US through CAMELS rating. CAMELS ratings proved to be effective in reflecting bank soundness (Meyer and Piffer 1970; Korobow and Stuhr 1975; Korobow et al. 1976; 1977; Pettway and Sinkey 1980 and Bovenzi et al. 1987). Basel Core Principles (BCP) on the other hand, represents the global standard for best practices in supervision and regulation. Demirgüç-Kunt and Detragiache (2011) noted that better compliance with BCP does not necessarily lead to improved bank soundness. Models such as Financial Soundness Indicators (FSI) 'core' series, monitors the soundness of the banks as Authorised Deposit-taking Institutions (ADI) (Costa Navajas and Thegeya 2013).

Demirgüç-Kunt et al. (2008) state that rating measures bank soundness accurately as credit rating system takes into account both quantitative and qualitative information on banks as well as the environment a bank operate. Moody denotes that BFSR (Bank Financial Strength Rating) measures the intrinsic soundness and safety of a bank. While Moody, Fitch and Standard \& Poor (S\&P) measures the ability of banks to meet their depositors and creditors obligations as they fall due. 
The study assembles seven sets of bank and credit rating indicators [Basel Core Principles (BCP), Financial Soundness Indicators (FSI), CAMELS, Moody, Fitch, S\&P and Bank Financial Strength Rating BFSR] to provide a meaningful insight on the indicators that contribute to bank soundness. Although several studies have assessed bank soundness in the past, only a few covered the two key areas of developed economies and soundness indicators [Gaganis et al. 2006; Demirgüç-Kunt et al. 2008; Demirgüç-Kunt and Detragiache 2011].

The core hypotheses tested through PLS-SEM is as follows:

\section{H1: Capital makes a significant contribution to bank soundness}

The quality and level of a bank's capital determines the survival of a bank. Bank capital acts as the last resort against losses to uninsured depositors, creditors and the Federal Deposit insurance corporation (FDIC). Therefore, insufficient capital during adversity could bring banks down.

\section{H2: Asset makes a significant contribution to bank soundness}

Banks that extends loans to credit worthy customers with sound collateral levels indicates low non-performing loans (NPL) and less exposure to excessive risk levels. Therefore, if banks have accumulated high NPL, bad debts and do not have quality collateral to back its loans then there is a lesser chance of survival.

\section{H3: Management makes a significant contribution to bank soundness}

The efficiency of the management structure lies in the ability of bank officers and managers to make decisions that contributes to bank soundness.

\section{H4: Earning makes a significant contribution to bank soundness}

Earnings is viewed as the first line of defense against adversity and loan defaults. Therefore, steady streams of earnings from solid operating base is vital for the survival of the banks.

\section{H5: Liquidity makes a significant contribution to bank soundness}


Banks' funding sources and liquid assets determines the ability of the bank to meet unforeseen deposit outflows. Banks that are unable to meet its daily liquidity needs could result in bank runs, thus an insolvent bank.

\section{H6: Sensitivity makes a significant contribution to bank soundness}

Market forces play a key role in bank stability. Banks are exposed to various market risks (interest rate risk, foreign exchange risk, price risk). Sensitivity ratio assesses the effect of changes in market risk on the earnings and capital of a bank.

Banks are also sensitive to growth. Bank size (large or small) plays a key role in bank soundness (Bell 1997; Hooks 1995; Ohlson 1980; Gunsel 2005; Nurazi and Evans 2005). The bigger a bank grows in size, the more stable and financially sound a bank is in comparison to smaller banks. This was evident during the GFC (Košak et al. 2015). As banks increase in size, they have better access to additional financing, risk diversification and dealing with liquidity problems thus have longer survival time and less likely to fail.

\section{Data collection}

The sample consists of 1,135 listed banks in G7 countries. Listed banks provide homogeneity in the comparison of banks within the economies. Banks chosen were under the Global Industry Classification Standard of banks (code 401010) in Osiris. Data was collected for the period 2003-2013 sourced from Osiris and Bankscope databases. The data was converted and averaged in US dollars.

The study collected 60 independent variables (in reference to Table A1, A2) and categorized them under CAMELS. In reference to Fama and French (1992) stock return explains microeconomic variables (firm sensitivity, earnings price ratio, leverage ratio and book to market equity) and futuristic thus able to measure bank's expected soundness. 
Summary statistics (Table A3) highlights substantial skewness and kurtosis outside the range of \pm 2.58 across the variables, thus failing to meet parametric assumptions. According to Cheng (2008), King and Wen (2011) and Rasli et al. (2013) archivebased financial accounting empirical studies often report non-normal datasets.

\section{Methodology}

The study applies a second-generation multivariate technique of PLS-SEM for several reasons. PLS-SEM Hair et al. (2017) integrates both econometric and psychometric analysis in its estimation (Fornell and Larcke, 1981). Therefore, it is the best measure for latent variables in empirical studies.

Although bank specific variables of CAMELS are observable through ratio analysis, these variables contain latent factors that are not directly observable. One example is the variables under the earnings cluster "return on average assets" and "return on average equity". Both of these variables are highly correlated among themselves but have small correlations with Capital, Asset, Management, Liquidity and Sensitivity variables. This suggests the presence of latent variable "profitability" or "earning" in Capital, Asset, Management and Liquidity variables, which is responsible for the observed correlations. In this respect, PLS-SEM works to understand the relationship among the variables by understanding the constructs that underlie them and how the latent factors drive the variation in the data.

Besides, PLS-SEM supports models with formative measurements, works with nonnormal distributed datasets, and most importantly, estimates cause-effect relationships amongst latent accounting variables.

Henseler et al. (2009) notes that the partial least square path model comprises of inner and outer models, which sets out the linear equation. The inner model highlights the relationship amongst the latent constructs.

The inner model is constructed as follows: 


$$
\xi=\mathrm{B} \xi+\zeta
$$

where $\xi$ stands for the vector of latent variables, B is the matrix of coefficients and $\zeta$ is the inner model residuals. The predictor specification reduces the inner model in Eq. (1) to:

$$
(\xi \mid \xi)=\mathrm{B} \xi
$$

The outer model predicts the relationship amongst the latent constructs and indicators. The outer model comprises of reflective and formative measurement models.

The reflective mode shows causal relationship from latent variable to manifest variables generated as a linear function of latent variables and residual $\varepsilon$ :

$$
\mathrm{X}_{\chi}=\Lambda_{\chi} \xi+\varepsilon_{\chi}
$$

where $\Lambda$ stands for the loading coefficients. The predictor specification reduces the outer model in Eq. (3) to:

$$
\left(\mathrm{X}_{\chi} \mid \xi\right)={ }_{\Lambda} \xi
$$

The formative shows causal relationship from manifest variables to latent variables. The linear relationship is as follows:

$$
\xi=\Pi_{\chi} \mathrm{X}_{\chi}+\varepsilon_{\chi}
$$

The predictor specification reduces Eq. (5) to:

$$
\left(\xi \mid X_{\chi}\right)=\Pi_{\chi} X_{\chi}
$$

PLS-SEM algorithm comprises of two stages. The first stage estimates the latent constructs' scores in four steps. The outer approximations of latent construct scores are estimated first. Then proxies for structural model relationships are established. Inner approximation of latent constructs scores is then considered while estimating the proxies for coefficients in the measurement models. The second stage calculates the final estimates of the outer weights and loadings and path coefficients (Lohmöller 1989). 


\section{Construct measures}

The model was initially designed with six exogenous constructs (CAMELS) of 60 manifest variables. In creating a parsimonious model, the manifest variables were reduced to 16 [3 capital(C), 4 assets (A), 2 management (M), 3 earnings (E), 3 liquidity (L), 1 sensitivity (S)]. In reference to Figure F1, path models visually show the relationships between the six hypotheses and manifest variables (Hair et al. 2011; Hair et al. 2017). The inner model (structural model) displays the relationships between constructs. While the outer model (measurement model) displays the relationship between the constructs and the manifest variables.

\section{Findings}

\section{Measurement mode}

Theoretical conceptualization supports the framework that CAMELS constructs are appropriate measures of stock returns, thus the proxy for bank soundness. The 16 manifest variables form the six CAMELS exogenous constructs. These constructs are modelled as formative measures for the endogenous construct of stock return (Figure F2).

\section{Formative measurement models}

The study follows Hair et al. (2017) in assessing the formative measures. Formative measures are expected to be free of errors (Diamantopoulos 2006; Edwards and Bagozzi 2000). The study presents a comprehensive set of formative indicators (Table A2) to show that the formative indicators encapsulate all the facets of the construct. Past literature shows strong support on content validity for the six dimensions of CAMELS as formative measures that forms bank soundness. 
The bootstrapping procedure was conducted to generate outer weights, outer loadings and path coefficients results. The bootstrapping procedure was run with a bootstrap sample of 10, 000 with "no sign change" option for the most conservative results.

In assessing the significance and the relevance of the formative indicators, the study examines the outer weights. Table A4 assembles the relative contribution of each manifest variables (in weights) thus, its significance in forming the constructs. The results show that some manifest variables have a low or even insignificant outer weights. Although the outer weight is insignificant, the outer loading is above 0.5. This indicates that the manifest variables have an absolute contribution to the constructs and is to be retained.

In assessing the formative measurements models for collinearity issues, the variance inflation factor (VIF) is noted (Table A4). The results show that all VIFs are below the threshold level of 5. Therefore, the presence of collinearity issues in manifest variables is not of a concern.

\section{Structural model}

The study managed to create a parsimonious model with a $\mathrm{R}^{2}$ value of $43.8 \%$. This indicates that $43.8 \%$. of the variance in the stock returns is explained by CAMELS constructs. Hair et al. (2011) and Henseler et al. (2009) evaluates this result as moderate. The model's predictive relevance $\left(Q^{2}\right)$ with regard to endogenous construct stands at a large category of 0.425 (see Hair et al. 2017).

\section{Analysis}

Effects of Capital on Stock returns

Capital construct failed to establish a significant relationship with stock returns $(\mathrm{p}=.987)$. Capital has no predictive relevance as $\mathrm{f}$ Square stands at 0.001 and is the 
least important construct with a weak path coefficient of -0.001 . Thus, rejecting hypothesis 1 . The negative sign indicates insufficient capital levels, despite adhering to Basel Core Principles. This validates Demirguc-Kunt et. al. (2008) point that mere adherence to Basel Core Principles does not guarantees a sound bank.

\section{Effects of Asset on Stock returns}

The findings highlight that asset has established a strong significance with a $\mathrm{p}$ value of 0.000. It has an average predictive relevance (f square 0.150) and is of an average importance with a path coefficient of -0.679 . Thus, supporting hypothesis 2 . The path coefficient highlights a negative relationship. This suggests that these countries had low levels of assets.

\section{Effects of Management on Stock returns}

Management construct shows a significant p-value of 0.002 at $99 \%$ confidence level. Thus, establishing a relationship between the constructs and supporting hypothesis 3 . However, management has no predictive relevance (f square 0.007) and a weak but positive path coefficient of 0.147 . This suggest that management is the least important construct. On contrary, Lindgreen et al. (1996) views internal governance (management) as the most important construct for a sound bank.

\section{Effects of Earnings on Stock returns}

The results suggest that there is no significant relationship between earnings and stock returns $(\mathrm{p}$-value $=0.715)$. A weak predictive relevance is evident with an $\mathrm{f}$ square that stands at 0.001 . The path coefficient displays a value of 0.032 suggesting that earnings have a weak but positive relationship with stock returns.

\section{Effects of Liquidity on Stock returns}

Liquidity construct highlights a weak path coefficient of -0.138 and no predictive relevance (f squares $=0.017)$ but a strong significance $(p=0.007)$. Therefore, 
supporting hypothesis 5. However, the path coefficient shows an adverse relationship suggesting that banks had insufficient liquidity buffer. Low liquidity levels result in dangerous bank runs. Ratnovski and Huang (2009) on the other hand, noted that banks in UK and US were relatively liquid.

\section{Effects of Sensitivity on Stock returns}

Large banks have strong significance $(\mathrm{p}=0.000)$, strong path coefficient of 1.150 and the largest predictive relevance (f square $=0.297$ ) on stock returns. Thus, supporting hypothesis 6 . The results suggest that large banks have larger stock returns. This finding is in line with Demirguc-Kunt et al. (2008) that big banks are well diversified and more stable, and thus are more sound. However, Gaganis et al. (2006) states that size of a bank does not determine bank soundness in developed countries. While Ho and Saunders (1980) suggested that large banks that has access to discount windows, had depositors who were partially insured were more susceptible of catastrophe than smaller banks.

In summary, the results (Table A5) strongly suggest that banks that were big in size were more sound. Asset, management and liquidity ratios played a significant role in determining bank soundness. However, banks were least focused on core business areas of taking deposits and giving out loans. Higher priority was placed on offbalance sheet activities and capital market investment thus taking on excessive risks. This explains the weak management, liquidity, capital and earnings ratios. Surprisingly, banks were also operating with insufficient capital and liquidity ratios which resembles the causes of bank failures (illiquidity, bad assets, overbanking and mismanagement) during the Great Depression (Tussing 1967).

Banks engage in financing long-term assets, fund short-term debts and carry out excessive amounts of maturity transformations. Aggressive withdrawal of funds during adversity could cause bank runs. Although Basel III established Net Stable Funding Ratio (NFSR) and Liquidity Coverage Ratio (LCR) with the intention to improve liquidity levels, the results from this study proves otherwise.

Despite the fact that capital is a strong determinant of bank status, capital showed no significance in bank soundness. As banks grow in size, capital needs to increase 
proportionately to cushion against market shocks. Basel III was formed with the understanding that higher bank capital results in financial stability. Conversely, Ratnovski and Huang (2009) and Währungsfonds (2009) found that banks with high capital levels in advanced economies exhausted capital to adversity during the GFC. Therefore, there is no conclusive answer whether increased capital levels helps during crisis periods.

\section{Conclusion}

In conclusion, the study represents and contributes to the notion that banks in G7 countries place significance on size as the most important and capital as the least important determinant of bank soundness. Banks in these countries were more focused on off balance sheet transactions and capital market investments which led to high risk levels. Despite adhering to Basel requirements, bank failures in these countries during the GFC was a result of low capital and liquidity levels. Many other factors could make capital and liquidity insufficient resulting in a crisis. Policy makers should further examine the existing capital framework and devise new policy measures that will create convergence with soundness. 


\section{Appendix}

Table A1. List of independent variables

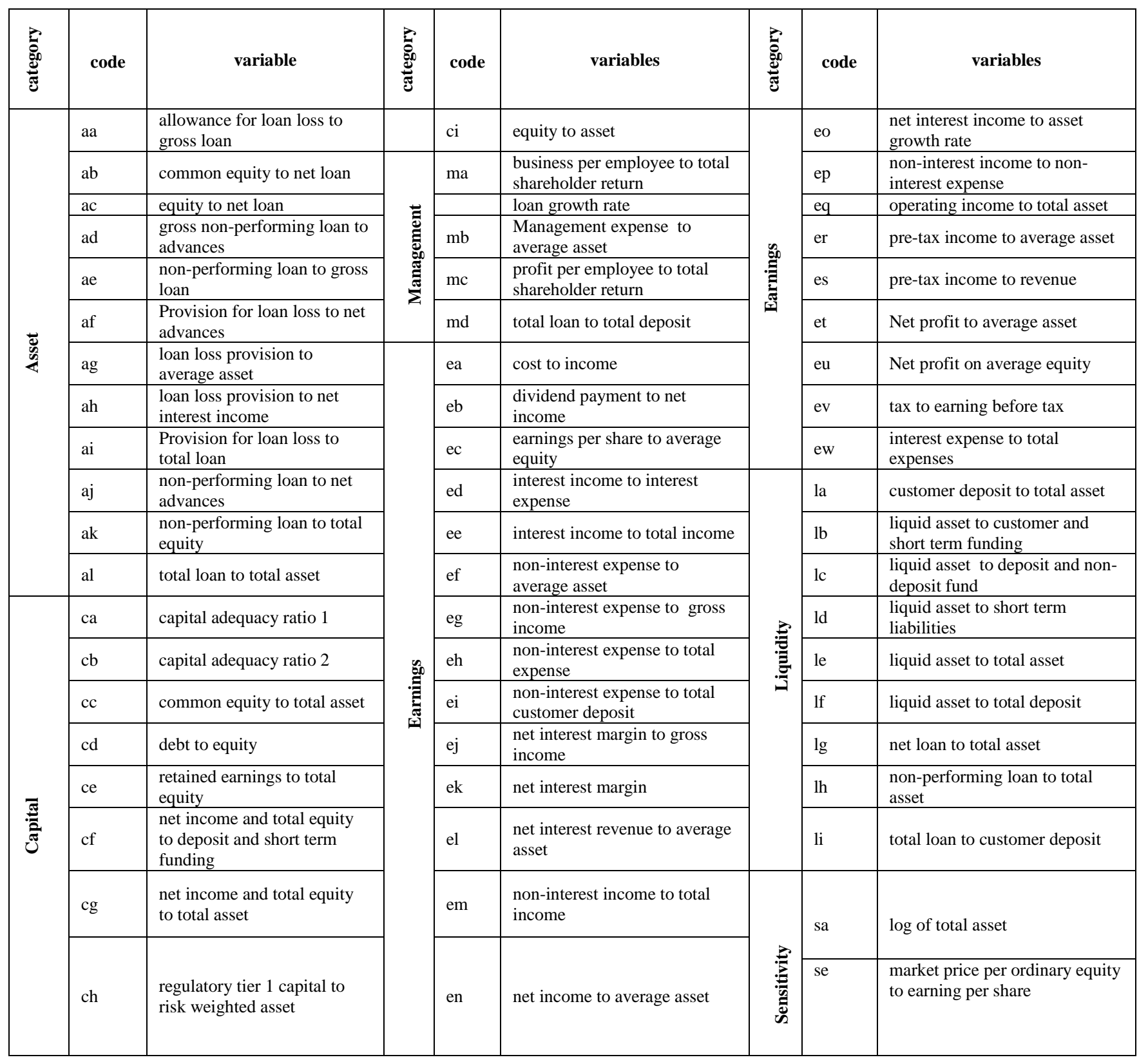


Table A2. List of variables with references

\begin{tabular}{|c|c|c|c|}
\hline \multirow[t]{2}{*}{ No } & Code & Variables & References \\
\hline & Dependent variable & Stock return & Fama and French (1992) \\
\hline & & & \\
\hline & Independent variable & & \\
\hline & & & \\
\hline & & Asset & \\
\hline 1 & aa & $\begin{array}{l}\text { Allowance for loan loss to } \\
\text { gross loan }\end{array}$ & Dang (2011) \\
\hline 2 & $\mathrm{ab}$ & Common equity to net loan & Poon et al.(1999) \\
\hline 3 & ac & Equity to net loan & Poon et al.(1999) \\
\hline 4 & $\mathrm{ad}$ & $\begin{array}{l}\text { Gross non-performing loan to } \\
\text { advances }\end{array}$ & Kumar et al. (2012) \\
\hline 5 & ae & $\begin{array}{l}\text { Nonperforming loans to gross } \\
\text { loans }\end{array}$ & $\begin{array}{l}\text { International Monetary Fund Staff } \\
(2008)\end{array}$ \\
\hline 6 & af & $\begin{array}{l}\text { Provision for loan loss to net } \\
\text { advances }\end{array}$ & Kumar et al. (2012) \\
\hline 7 & ag & $\begin{array}{l}\text { Loan loss provision to average } \\
\text { asset }\end{array}$ & Poon et al.(1999) \\
\hline 8 & $\mathrm{ah}$ & $\begin{array}{l}\text { Loan loss provision to net } \\
\text { interest income }\end{array}$ & Loannidis et al.(2010) \\
\hline 9 & ai & $\begin{array}{l}\text { Provision for loan loss to total } \\
\text { loans }\end{array}$ & Kumar et al. (2012) \\
\hline 10 & aj & $\begin{array}{l}\text { Non-performing loan to net } \\
\text { advances }\end{array}$ & Kumar et al. (2012) \\
\hline 11 & ak & $\begin{array}{l}\text { Non-performing loan to total } \\
\text { equity }\end{array}$ & Dang (2011) \\
\hline \multirow[t]{2}{*}{12} & al & Total loan to total asset & Kumar et al. (2012) \\
\hline & & Capital & \\
\hline 13 & $\mathrm{ca}$ & Capital adequacy ratio(1) & Dang (2011) \\
\hline 14 & $\mathrm{cb}$ & Capital adequacy ratio(2) & Kumar et al. (2012) \\
\hline 15 & $\mathrm{cc}$ & Common equity to total asset & Poon et al.(1999) \\
\hline 16 & $\mathrm{~cd}$ & Debt to equity & N.S. Toor, (2009) \\
\hline 17 & ce & $\begin{array}{l}\text { Retained earnings to total } \\
\text { equity }\end{array}$ & Sarker (2006) \\
\hline 18 & $\mathrm{cf}$ & $\begin{array}{l}\text { Net income and total equity to } \\
\text { deposit and short term funding }\end{array}$ & Canbas et al.(2005) \\
\hline 19 & $\mathrm{cg}$ & $\begin{array}{l}\text { Net income and total equity to } \\
\text { total asset }\end{array}$ & Canbas et al.(2005) \\
\hline 20 & $\mathrm{ch}$ & $\begin{array}{l}\text { Regulatory Tier } 1 \text { capital to } \\
\text { risk weighted assets }\end{array}$ & $\begin{array}{l}\text { International Monetary Fund Staff } \\
\text { (2008) }\end{array}$ \\
\hline \multirow[t]{2}{*}{21} & $\mathrm{ci}$ & Total equity to total asset & Loannidis et al.(2010) \\
\hline & & Management & \\
\hline 22 & ma & $\begin{array}{l}\text { Business per employee to total } \\
\text { shareholder return }\end{array}$ & Kumar et al. (2012) \\
\hline 23 & & Loan growth rate & Dang (2011) \\
\hline 24 & $\mathrm{mb}$ & $\begin{array}{l}\text { Management expense to } \\
\text { average asset }\end{array}$ & Kumar et al. (2012) \\
\hline 25 & $\mathrm{mc}$ & $\begin{array}{l}\text { Profit per employee to total } \\
\text { shareholder return }\end{array}$ & Kumar et al. (2012) \\
\hline \multirow[t]{2}{*}{26} & md & Total loan to total deposit & Kumar et al. (2012) \\
\hline & & Earnings & \\
\hline 27 & ea & Cost to income & Dang (2011) \\
\hline
\end{tabular}




\begin{tabular}{|c|c|c|c|}
\hline 28 & $\mathrm{eb}$ & $\begin{array}{l}\text { Dividend payment to net } \\
\text { income }\end{array}$ & Poon et al.(1999) \\
\hline 29 & ec & $\begin{array}{l}\text { Earning per share to average } \\
\text { equity }\end{array}$ & N.S. Toor (2009) \\
\hline 30 & ed & $\begin{array}{l}\text { Interest income to interest } \\
\text { expense }\end{array}$ & Canbas et al.(2005) \\
\hline 31 & ee & Interest income to total income & N.S. Toor (2009) \\
\hline 32 & ef & $\begin{array}{l}\text { Non-interest expenditure to } \\
\text { average asset }\end{array}$ & Loannidis et al.(2010) \\
\hline 33 & eg & $\begin{array}{l}\text { Non-interest expense to gross } \\
\text { income }\end{array}$ & $\begin{array}{l}\text { International Monetary Fund Staff } \\
(2008)\end{array}$ \\
\hline 34 & eh & $\begin{array}{l}\text { Non interest expenses to total } \\
\text { expense }\end{array}$ & $\begin{array}{l}\text { International Monetary Fund Staff } \\
(2008)\end{array}$ \\
\hline 35 & ei & $\begin{array}{l}\text { Non interest expense/ Total } \\
\text { Deposit }\end{array}$ & Poon et al.(1999) \\
\hline 36 & ej & $\begin{array}{l}\text { Interest margin to gross } \\
\text { income }\end{array}$ & $\begin{array}{l}\text { International Monetary Fund Staff } \\
(2008)\end{array}$ \\
\hline 37 & $\mathrm{ek}$ & Net interest margin & Poon et al.(1999) \\
\hline 38 & el & $\begin{array}{l}\text { Net interest revenue to average } \\
\text { asset }\end{array}$ & Dang (2011) \\
\hline 39 & $\mathrm{em}$ & $\begin{array}{l}\text { Non-interest income to total } \\
\text { income }\end{array}$ & N.S. Toor (2009) \\
\hline 40 & en & Net income to average asset & Poon et al.(1999) \\
\hline 41 & eo & $\begin{array}{l}\text { Net interest income to asset } \\
\text { growth rate }\end{array}$ & Dang (2011) \\
\hline 42 & ep & $\begin{array}{l}\text { Non-interest income to non- } \\
\text { interest expense }\end{array}$ & $\begin{array}{l}\text { International Monetary Fund Staff } \\
(2008)\end{array}$ \\
\hline 43 & eq & Operating profit to total asset & Gasbarro et al.(2002) \\
\hline 44 & er & $\begin{array}{l}\text { Pre-tax income to average } \\
\text { asset }\end{array}$ & Poon et al.(1999) \\
\hline 45 & es & Pre-tax income to revenue & Poon et al.(1999) \\
\hline 46 & et & Net profit to average asset & Kumar et al. (2012) \\
\hline 47 & $\mathrm{eu}$ & Net profit on average equity & Demirgüç-Kunt et al.(2008) \\
\hline 48 & ev & Tax to earning before tax & Poon et al.(1999) \\
\hline \multirow[t]{2}{*}{49} & ew & $\begin{array}{l}\text { Interest expense to total } \\
\text { expenses }\end{array}$ & Canbas et al.(2005) \\
\hline & & Liquidity & \\
\hline 50 & la & $\begin{array}{l}\text { Customer deposits to total } \\
\text { assets }\end{array}$ & Dang (2011) \\
\hline 51 & $\mathrm{lb}$ & $\begin{array}{l}\text { Liquid asset to customer and } \\
\text { short term funding }\end{array}$ & Loannidis et al.(2010) \\
\hline 52 & lc & $\begin{array}{l}\text { Liquid asset to deposit and } \\
\text { non deposit fund }\end{array}$ & Canbas et al.(2005) \\
\hline 53 & ld & $\begin{array}{l}\text { Liquid asset to short term } \\
\text { liabilities }\end{array}$ & $\begin{array}{l}\text { International Monetary Fund Staff } \\
(2008)\end{array}$ \\
\hline 54 & le & Liquid asset to total asset & Poon et al.(1999) \\
\hline 55 & If & Liquid assets to total deposit & Kumar et al. (2012) \\
\hline 56 & $\lg$ & Net loan to total asset & Demirgüç-Kunt et al.(2008) \\
\hline 57 & lh & $\begin{array}{l}\text { Non performing loan to total } \\
\text { asset }\end{array}$ & Gasbarro et al.(2002) \\
\hline \multirow[t]{2}{*}{58} & li & Total loan to customer deposit & Dang (2011) \\
\hline & & Sensitivity & \\
\hline 59 & sa & Log of total asset & Košak et al.(2015) \\
\hline 60 & se & $\begin{array}{l}\text { Market price per ordinary } \\
\text { equity to earning per share }\end{array}$ & Nurazi, R., \& Evans, M. (2005) \\
\hline
\end{tabular}


Table A3. Summary statistics

\begin{tabular}{|c|c|c|c|c|c|c|c|c|c|}
\hline & No. & Missing & Mean & Median & Min & $\operatorname{Max}$ & Standard Deviation & Excess Kurtosis & Skewness \\
\hline bank code & 1 & 0 & 568 & 568 & 1 & $1,135.00$ & 327.646 & -1.2 & 0 \\
\hline country & 2 & 0 & 6.653 & 7 & 1 & 7 & 1.08 & 12.252 & -3.558 \\
\hline aa & 3 & 0 & 0.005 & 0.004 & -0.034 & 0.044 & 0.005 & 6.789 & 1.084 \\
\hline$a b$ & 4 & 0 & 0.468 & 0.078 & -0.01 & 391.624 & 11.623 & $1,132.19$ & 33.628 \\
\hline $\mathrm{ac}$ & 5 & 0 & 1.746 & 1.818 & -2.959 & 5.607 & 0.913 & 0.777 & -0.04 \\
\hline $\mathrm{ad}$ & 6 & 0 & 0.022 & 0.017 & -0.032 & 0.329 & 0.024 & 29.6 & 3.385 \\
\hline $\mathrm{ae}$ & 7 & 0 & 0.546 & 0.476 & 0 & 2.16 & 0.437 & 0.436 & 0.915 \\
\hline af & 8 & 0 & -271.263 & 4.368 & $-46,770.83$ & 16.36 & $2,277.55$ & 224.483 & -13.8 \\
\hline ag & 9 & 0 & 0.004 & 0.002 & -0.015 & 0.804 & 0.024 & $1,093.91$ & 32.775 \\
\hline ah & 10 & 0 & 1.229 & 1.346 & -82.364 & 4.331 & 2.718 & 789.426 & -25.822 \\
\hline ai & 11 & 0 & 0.005 & 0.004 & -0.032 & 0.329 & 0.011 & 732.236 & 24.324 \\
\hline aj & 12 & 0 & 0.017 & 0.012 & 0 & 0.2 & 0.019 & 11.675 & 2.407 \\
\hline ak & 13 & 0 & -4.779 & 0.051 & $-5,464.99$ & 1.286 & 162.147 & $1,134.94$ & -33.688 \\
\hline al & 14 & 0 & 0.447 & 0.475 & 0 & 0.899 & 0.218 & -1.194 & -0.21 \\
\hline $\mathrm{sp}$ & 15 & 0 & 1.698 & 0.639 & -0.944 & 12.539 & 2.261 & 2.576 & 1.576 \\
\hline $\mathrm{ca}$ & 16 & 0 & $-5,353.14$ & 2.362 & $-3,395,496.41$ & 18.469 & $112,745.59$ & 759.94 & -26.731 \\
\hline $\mathrm{cb}$ & 17 & 0 & -56.921 & 2.545 & $-40,088.36$ & 18.485 & $1,236.74$ & 970.117 & -30.261 \\
\hline $\mathrm{cc}$ & 18 & 0 & 0.054 & 0.039 & -0.004 & 1.572 & 0.075 & 162.659 & 9.656 \\
\hline $\mathrm{cd}$ & 19 & 0 & 0.948 & 1.571 & -238.073 & 3.809 & 8.385 & 622.557 & -23.437 \\
\hline ce & 20 & 0 & $-31,283.43$ & 3.019 & $-10,931,475.66$ & 16.585 & $396,921.78$ & 535.916 & -21.497 \\
\hline $\mathrm{cf}$ & 21 & 0 & $-2,858.10$ & 6.733 & $-2,920,521.90$ & 18.79 & $86,838.79$ & $1,124.74$ & -33.47 \\
\hline $\mathrm{cg}$ & 22 & 0 & -47.057 & 6.831 & $-8,737.47$ & 18.79 & 515.555 & 152.561 & -11.831 \\
\hline ch & 23 & 0 & 0.028 & 0.02 & -21.726 & 0.701 & 0.65 & $1,106.27$ & -33.044 \\
\hline $\mathrm{ci}$ & 24 & 0 & 0.051 & 0.063 & -21.696 & 0.912 & 0.649 & $1,115.77$ & -33.256 \\
\hline
\end{tabular}




\begin{tabular}{|c|c|c|c|c|c|c|c|c|c|}
\hline $\mathrm{ma}$ & 25 & 0 & 5.225 & 5.533 & -16.853 & 12.227 & 2.919 & 1.455 & -0.562 \\
\hline $\mathrm{mb}$ & 26 & 0 & 7.127 & 4.076 & -13.95 & 123.12 & 11.964 & 27.745 & 4.374 \\
\hline $\mathrm{mc}$ & 27 & 0 & 0.002 & 0.018 & -21.713 & 0.308 & 0.645 & $1,133.11$ & -33.647 \\
\hline md & 28 & 0 & 13.712 & 11.031 & -207.799 & 425.136 & 32.436 & 30.538 & 2.284 \\
\hline me & 29 & 0 & 0.592 & 0.599 & -21.066 & 29.021 & 1.282 & 362.538 & 9.946 \\
\hline ea & 30 & 0 & 2.893 & 3.218 & 0 & 4.909 & 1.331 & -1.275 & -0.411 \\
\hline $\mathrm{eb}$ & 31 & 0 & -0.26 & 0.863 & -105.758 & 4.981 & 7.501 & 72.882 & -7.544 \\
\hline $\mathrm{ec}$ & 32 & 0 & -0.742 & 0.007 & -232.336 & 4.231 & 10.639 & 346.851 & -17.836 \\
\hline ed & 33 & 0 & 0.628 & 0.638 & -21.617 & 3.116 & 0.912 & 312.066 & -12.319 \\
\hline ee & 34 & 0 & -0.794 & 0.411 & -491.562 & 2.893 & 15.703 & 844.2 & -27.517 \\
\hline ef & 35 & 0 & 0.778 & 0.762 & -21.188 & 3.108 & 0.795 & 514.299 & -18.549 \\
\hline eg & 36 & 0 & 0.373 & 0.387 & -21.524 & 2.414 & 0.687 & 909.082 & -28.5 \\
\hline eh & 37 & 0 & 0.435 & 0.443 & -21.475 & 1 & 0.696 & 866.626 & -27.519 \\
\hline ei & 38 & 0 & 0.011 & 0.024 & -21.708 & 2.744 & 0.651 & $1,091.89$ & -32.651 \\
\hline ej & 39 & 0 & -0.019 & 0 & -21.726 & 0.004 & 0.645 & $1,135.00$ & -33.69 \\
\hline ek & 40 & 0 & 0.793 & 0.764 & -20.989 & 1.886 & 0.778 & 541.884 & -19.346 \\
\hline el & 41 & 0 & 0.733 & 0.717 & -21.012 & 1.778 & 0.76 & 591.024 & -20.647 \\
\hline $\mathrm{em}$ & 42 & 0 & -0.145 & 0.22 & -149.256 & 1.682 & 5.055 & 676.582 & -24.037 \\
\hline en & 43 & 0 & -0.018 & 0.003 & -21.722 & 0.021 & 0.645 & $1,132.31$ & -33.631 \\
\hline eo & 44 & 0 & $-90,708.91$ & -497.266 & $-12,251,161.60$ & 14.135 & $672,672.78$ & 211.093 & -13.427 \\
\hline ep & 45 & 0 & 0.188 & 0.171 & -21.651 & 0.83 & 0.67 & 998.997 & -30.6 \\
\hline eq & 46 & 0 & -0.015 & 0.004 & -21.719 & 0.032 & 0.645 & $1,134.60$ & -33.681 \\
\hline er & 47 & 0 & 0.096 & 0.137 & -21.529 & 0.519 & 0.771 & 572.872 & -22.028 \\
\hline es & 48 & 0 & -0.072 & 0.13 & -59.849 & 0.892 & 2.17 & 542.106 & -21.524 \\
\hline et & 49 & 0 & -1.183 & 0.144 & -987.96 & 0.946 & 29.877 & $1,051.34$ & -32 \\
\hline eu & 50 & 0 & 0.018 & 0.141 & -21.251 & 0.839 & 0.939 & 316.717 & -15.464 \\
\hline ev & 51 & 0 & -1.551 & 0.537 & -80.799 & 3.165 & 6.266 & 35.161 & -4.578 \\
\hline ew & 52 & 0 & 0.198 & 0.191 & -21.432 & 0.929 & 0.661 & $1,014.08$ & -30.949 \\
\hline
\end{tabular}




\begin{tabular}{|c|c|c|c|c|c|c|c|c|c|}
\hline la & 53 & 0 & 0.502 & 0.539 & -21.357 & 0.941 & 0.7 & 837.769 & -26.842 \\
\hline $\mathrm{lb}$ & 54 & 0 & 0.121 & 0.092 & 0 & 1.522 & 0.121 & 30.188 & 4.165 \\
\hline lc & 55 & 0 & 1.222 & 1.142 & -21.039 & 4.044 & 1.029 & 192.081 & -8.63 \\
\hline ld & 56 & 0 & 1.265 & 1.179 & -20.874 & 4.443 & 1.057 & 168.947 & -7.699 \\
\hline le & 57 & 0 & 0.628 & 0.712 & -21.185 & 1 & 0.719 & 746.323 & -24.638 \\
\hline If & 58 & 0 & 0.185 & 0.124 & 0 & 3.796 & 0.249 & 54.62 & 5.736 \\
\hline $\lg$ & 59 & 0 & 2.271 & 2.267 & -21.726 & 4.43 & 1.693 & 33.697 & -2.497 \\
\hline lh & 60 & 0 & -0.007 & 0.008 & -21.724 & 0.168 & 0.645 & $1,134.04$ & -33.668 \\
\hline li & 61 & 0 & 0.457 & 0.455 & -21.622 & 3.735 & 0.725 & 759.893 & -24.734 \\
\hline $\mathrm{sa}$ & 62 & 0 & 4.291 & 4.503 & 0 & 9.296 & 2.067 & -0.927 & -0.058 \\
\hline $\mathrm{se}$ & 63 & 0 & 3.161 & 0.065 & $-2,375.495$ & 630.914 & 81.690 & 640.643 & -21.619 \\
\hline
\end{tabular}


Table A4. Results for bank soundness constructs and manifest variables

\begin{tabular}{|c|c|c|c|c|c|c|c|c|}
\hline $\begin{array}{l}\text { Bank Soundness } \\
\text { Constructs }\end{array}$ & $\begin{array}{l}\text { Bank soundness } \\
\text { manifest } \\
\text { variables }\end{array}$ & Outer Weights & Outer Loadings & $\begin{array}{l}\text { Path } \\
\text { Coefficients }\end{array}$ & $\mathrm{t}$ Values & $\mathrm{p}$ Values & f Square & VIF \\
\hline Test criterion & & & $>0.5$ & & $\begin{array}{c}2.583(1 \% \\
\text { level) } \\
1.963(5 \% \\
\text { level) } \\
1.646(10 \% \\
\text { level) }\end{array}$ & $\begin{array}{c}<0.1(10 \% \\
\text { level) } \\
<0.05(5 \% \\
\text { level) } \\
<0.01(1 \% \\
\text { level) }\end{array}$ & $\begin{array}{c}\text { Small } 0.02 \\
\text { Medium } 0.15 \\
\text { Large } 0.35\end{array}$ & $<5$ \\
\hline \multirow[t]{4}{*}{ Asset } & aa & 0.068 & 0.570 & -0.679 & 9.653 & 0.000 & 0.150 & 1.460 \\
\hline & $\mathrm{ac}$ & 0.429 & 0.854 & & & & & 1.900 \\
\hline & ae & 0.312 & 0.780 & & & & & 1.898 \\
\hline & al & 0.386 & 0.912 & & & & & 2.645 \\
\hline \multirow[t]{3}{*}{ Capital } & $\mathrm{ca}$ & 0.580 & 0.697 & -0.001 & 0.016 & 0.987 & 0.000 & 1.227 \\
\hline & $\mathrm{cd}$ & -0.681 & -0.687 & & & & & 1.000 \\
\hline & $\mathrm{cf}$ & 0.255 & 0.504 & & & & & 1.227 \\
\hline \multirow[t]{3}{*}{ Earnings } & ea & 0.556 & 0.765 & 0.032 & 0.365 & 0.715 & 0.001 & 1.349 \\
\hline & ed & 0.499 & 0.876 & & & & & 1.895 \\
\hline & $\mathrm{eu}$ & 0.263 & 0.525 & & & & & 1.555 \\
\hline \multirow[t]{3}{*}{ Liquidity } & $\mathrm{lb}$ & 0.434 & 0.852 & -0.138 & 2.714 & 0.007 & 0.017 & 1.999 \\
\hline & If & 0.402 & 0.800 & & & & & 1.896 \\
\hline & $\lg$ & 0.455 & 0.678 & & & & & 1.107 \\
\hline \multirow[t]{2}{*}{ Management } & ma & 0.639 & 0.795 & 0.147 & 3.126 & 0.002 & 0.018 & 1.066 \\
\hline & md & 0.626 & 0.786 & & & & & 1.066 \\
\hline Sensitivity & $\mathrm{sa}$ & 1.000 & 1.000 & 1.150 & 10.284 & 0.000 & 0.297 & 1.000 \\
\hline Stock return & $\mathrm{sr}$ & 1.000 & 1.000 & & & & & 1.000 \\
\hline
\end{tabular}


Table A5. Results summary

\begin{tabular}{|l|r|r|r|}
\hline & $\begin{array}{r}\text { Path } \\
\text { Coefficients }\end{array}$ & $\mathrm{p}$ Values & f Square \\
\hline $\begin{array}{l}\text { Asset -> Stock } \\
\text { returns }\end{array}$ & $\boldsymbol{\nabla}$ & $\star$ & + \\
\hline $\begin{array}{l}\text { Capital -> } \\
\text { Stock returns }\end{array}$ & $\bullet \nabla$ & $\bullet$ & $\bullet$ \\
\hline $\begin{array}{l}\text { Earnings -> } \\
\text { Stock returns }\end{array}$ & $\bullet$ & $\bullet$ & $\bullet$ \\
\hline $\begin{array}{l}\text { Liquidity -> } \\
\text { Stock returns }\end{array}$ & $\bullet$ & $\star$ & $\bullet$ \\
\hline $\begin{array}{l}\text { Management - } \\
>\text { Stock returns }\end{array}$ & $\bullet$ & $\star$ & $\star$ \\
\hline $\begin{array}{l}\text { Sensitivity -> } \\
\text { Stock returns }\end{array}$ & $\star$ & $\star$ & $\star$ \\
\hline
\end{tabular}

Note:

$\boldsymbol{\bullet}=$ Weak

$\boldsymbol{\nabla}=$ Negative

$\boldsymbol{+}=$ Moderate

$\star=$ Exceptional

Weakest

Strongest

Capital Earnings Liquidity Management Asset Sensitivity 
Table A6. Summary of correlations

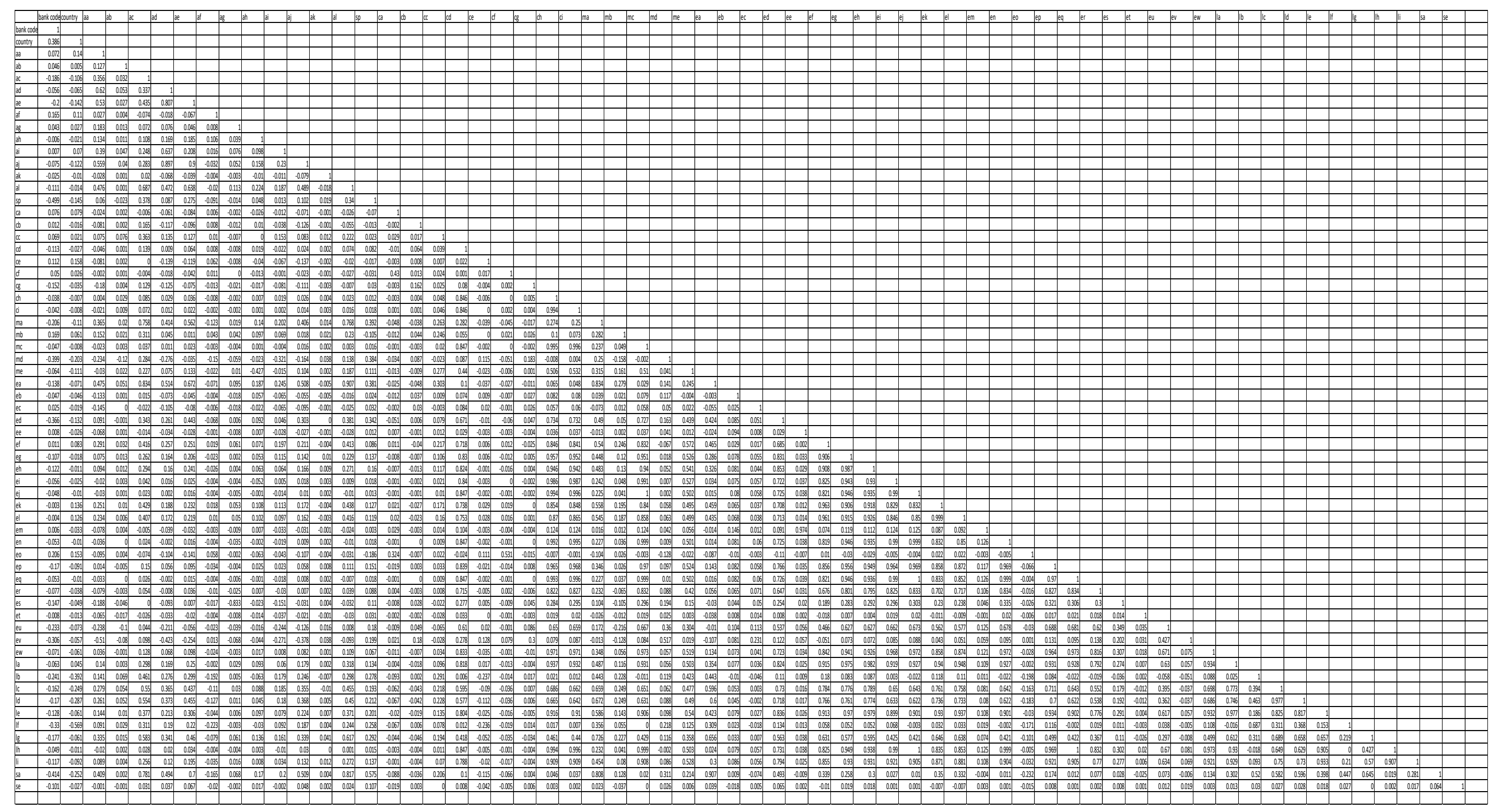


Figure F1. Structural model/Inner model and the Measurement model/Outer model

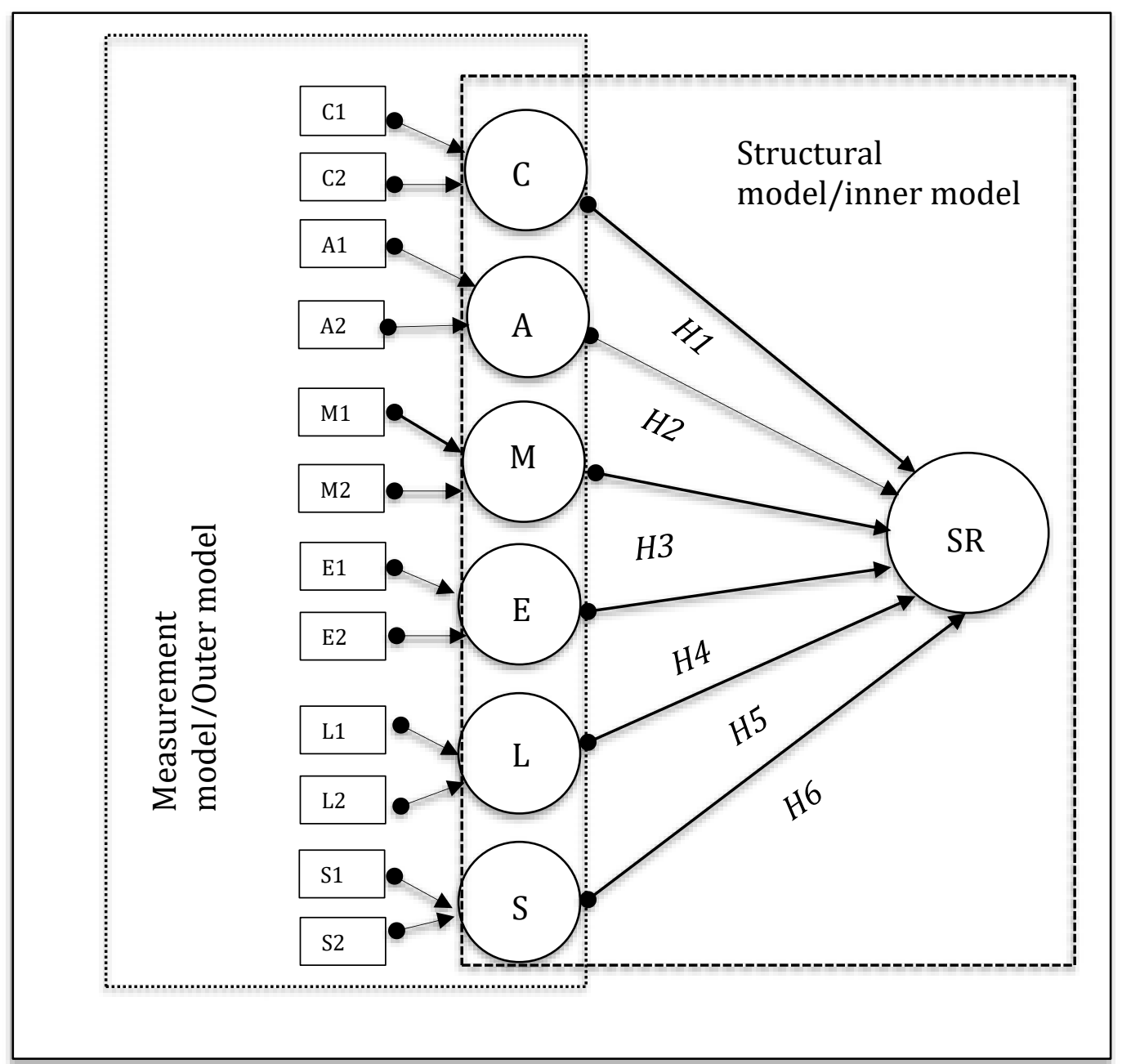


Figure F2. PLS-SEM results 


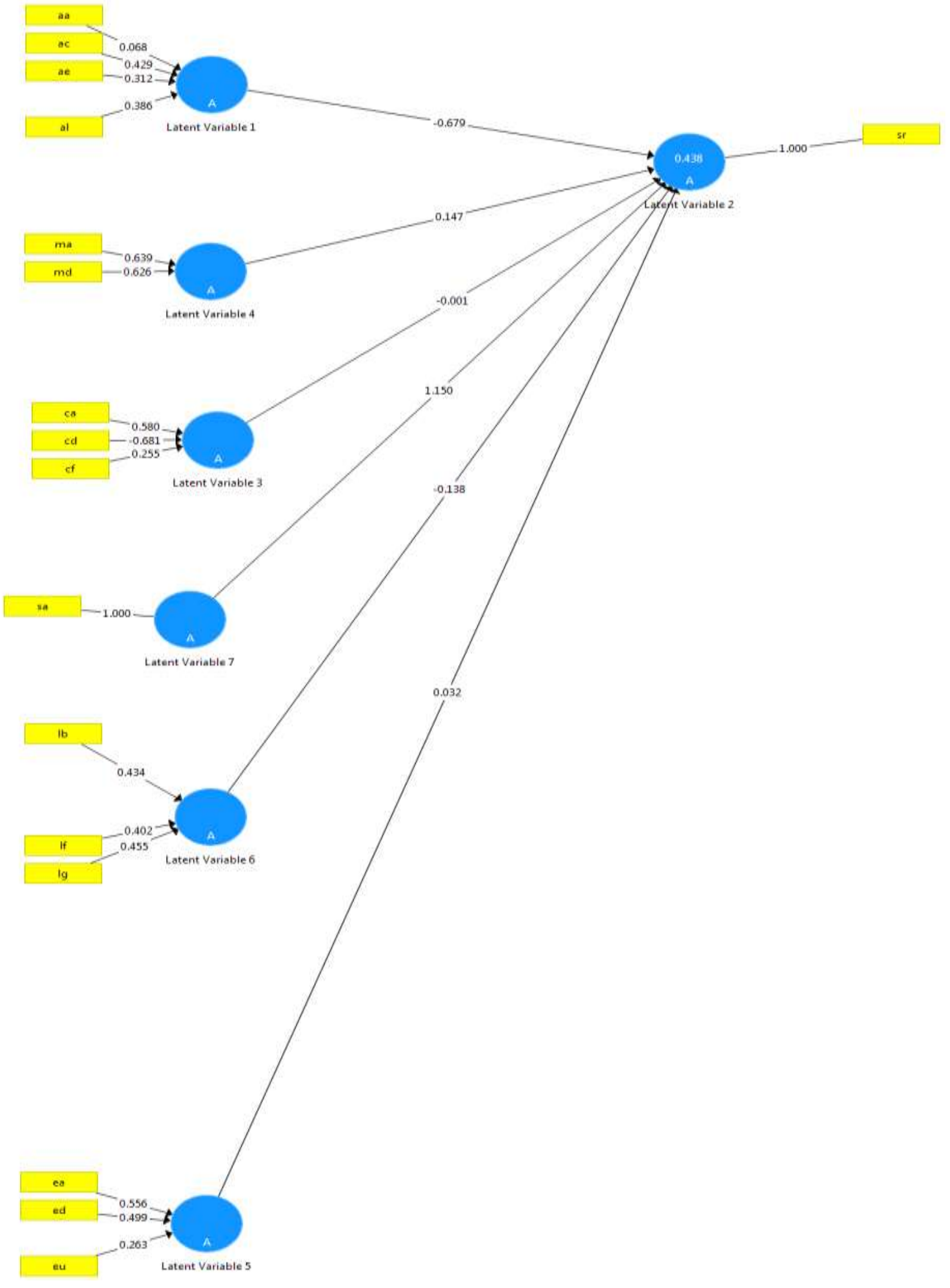




\section{References}

Bernanke, B. (2007). Global imbalances: recent developments and prospects. Bundesbank Lecture speech, September, 4, 18.

Bell, T. B. (1997). Neural nets or the logit model? A comparison of each model's ability to predict commercial bank failures. Intelligent Systems in Accounting, Finance and Management, 6(3), 249-264.

Bovenzi, J. F., Marino, J. A., \& McFadden, F. E. (1987). Commercial bank failure prediction models. in D.Johannes Juttner and Tom Valentine (Eds), The Economics and Management of Financial Institutions, Melbourne, Australia: Longman Cheshire Pty. Ltd., 419-436.

Canbas, S., Cabuk, A., \& Kilic, S. B. (2005). Prediction of commercial bank failure via multivariate statistical analysis of financial structures: The Turkish case. European Journal of Operational Research, 166(2), 528-546.

Cheng, S. (2008). Board sensitivity and the variability of corporate performance.Journal of financial economics, 87(1), 157-176.

Costa Navajas, M., \& Thegeya, A. (2013). Financial soundness indicators and banking crises.

Dang, U. (2011). The CAMEL Rating System in Banking Supervision: a Case Study of Arcada University of Applied Sciences. International Business.

Demirgüç-Kunt, A., Detragiache, E., \& Tressel, T. (2008). Banking on the principles: Compliance with Basel Core Principles and bank soundness.Journal of Financial Intermediation, 17(4), 511-542.

Demirgüç-Kunt, A., \& Detragiache, E. (2011). Basel Core Principles and bank soundness: Does compliance matter? Journal of Financial Stability, 7(4), 179-190. 
Diamantopoulos, A. (2006). The error term in formative measurement models: interpretation and modeling implications. Journal of Modelling in Management, 1(1), $7-17$.

Edwards, J. R., \& Bagozzi, R. P. (2000). On the nature and direction of relationships between constructs and measures. Psychological methods,5(2), 155.

Fama, E.F., French, K.R. (1992). The Cross-Section of Expected Stock Returns. The Journal of Finance, 47 (2), 427-465.

Fornell, C., \& Larcker, D. F. (1981). Evaluating structural equation models with unobservable variables and measurement error. Journal of marketing research, 39-50.

Gasbarro, D., Sadguna, I. G. M., \& Zumwalt, J. K. (2002). The changing relationship between CAMEL ratings and bank soundness during the Indonesian banking crisis. Review of Quantitative Finance and Accounting,19(3), 247-260.

Gaganis, C., Pasiouras, F., \& Zopounidis, C. (2006). A multicriteria decision framework for measuring banks' soundness around the world. Journal of MultiCriteria Decision Analysis, 14(1-3), 103-111.

Gunsel, N. (2005). Financial ratios and the probabilistic prediction of bank failure in North Cyprus. Editorial Advisory Board e, 18(2), 191-200.

Hair, J. F., Ringle, C. M., \& Sarstedt, M. (2011). PLS-SEM: Indeed a silver bullet. Journal of Marketing theory and Practice, 19(2), 139-152.

Hair, J. F., Sarstedt, M., Pieper, T. M., \& Ringle, C. M. (2012). The use of partial least squares structural equation modeling in strategic management research: a review of past practices and recommendations for future applications. Long range planning, 45(5), 320-340.

Hair Jr, J. F., Hult, G. T. M., Ringle, C., \& Sarstedt, M. (2017). A primer on partial least squares structural equation modeling (PLS-SEM). Sage Publications. 
Hanc, G. (1998). The banking crises of the 1980s and early 1990s: Summary and implications. FDIC Banking Rev., 11, 1.

Henseler, J., Ringle, C. M., \& Sinkovics, R. R. (2009). The use of partial least squares path modeling in international marketing. In New challenges to international marketing (pp. 277-319). Emerald Group Publishing Limited.

Henseler, J., Ringle, C. M., \& Sarstedt, M. (2015). A new criterion for assessing discriminant validity in variance-based structural equation modeling. Journal of the Academy of Marketing Science, 43(1), 115-135.

Ho, T., \& Saunders, A. (1980). A catastrophe model of bank failure. The Journal of Finance, 35(5), 1189-1207.

Hooks, L. M. (1995). Bank asset risk: Evidence from early-warning models. Contemporary Economic Policy, 13(4), 36-50.

International Monetary Fund Staff (2008). Financial Soundness Indicators: Compilation Guide. International Monetary Fund.

King, T. H. D., \& Wen, M. M. (2011). Shareholder governance, bondholder governance, and managerial risk-taking. Journal of Banking \& Finance,35(3), 512531.

Korobow, L., \& Stuhr, D. P. (1975). Toward early warning of changes in bank's financial condition: a progress report. na.

Korobow, L. E. O. N., Stuhr, D. P., \& Martin, D. (1976). A probabilistic approach to early warning of changes in bank financial condition. Monthly Review, 7, 187-194.

Korobow, L., Stuhr, D. P., \& Martin, D. (1977). A nationwide test of early warning research in banking. Quarterly Review, 59(3), 37-52. 
Košak, M., Li, S., Lončarski, I., \& Marinč, M. (2015). Quality of bank capital and bank lending behavior during the global financial crisis. International review of financial analysis, 37, 168-183.

Kumar, M. A., Harsha, G. S., Anand, S., \& Dhruva, N. R. (2012). Analyzing Soundness in Indian Banking: A CAMEL Approach. Research Journal of Management Sciences, 1(3), 9-14.

Loannidis, C., Pasiouras, F., \& Zopounidis, C. (2010). Assessing bank soundness with classification techniques. Omega, 38(5), 345-357.

Lindgren, C.J., Garcia, G., \& Saal. M. (1996). Bank Soundness and Macroeconomic Policy. IMF Occasional Papers, No. 135, Washington DC.

Lohmöller, J. B. (2013). Latent variable path modeling with partial least squares. Springer Science \& Business Media.

Meyer, P. A., \& Pifer, H. W. (1970). Prediction of bank failures. The Journal of Finance, 25(4), 853-868.

N.S. TOOR., 2009. Handbook Of Banking Information

Nurazi, R., \& Evans, M. (2005). An Indonesian study of the use of CAMEL (S) ratios as predictors of bank failure. Journal of Economic and Social Policy, 10(1), 6.

Ohlson, J. A. (1980). Financial ratios and the probabilistic prediction of bankruptcy. Journal of accounting research, 109-131.

Pettway, R. H., \& Sinkey, J. F. (1980). Establishing On-Site Bank Examination Priorities: An Early-Warning System Using Accounting and Market Information. The Journal of Finance, 35(1), 137-150. 
Podviezko, A., \& Ginevičius, R. (2010). Economic criteria characterising bank soundness and stability. 6th International Scientific Conference, May 13-14, 2010, Vilnius, Lithuania. Business and Management 2010.

Poon, W. P., Firth, M., \& Fung, H. G. (1999). A multivariate analysis of the determinants of Moody's bank financial strength ratings. Journal of International Financial Markets, Institutions and Money, 9(3), 267-283.

Rasli, A., Goh, C. F., \& Khan, S. U. R. (2013). Demystifying the role of a state ownership in corporate governance and firm performance: evidence from the manufacturing sector in Malaysia. Zbornik radova Ekonomskog fakulteta u Rijeci: časopis za ekonomsku teoriju i praksu, 31(2), 233-252.

Ratnovski, L., \& Huang, R. (2009). Why are Canadian banks more resilient? IMF Working Paper, 152 (9).

Schaeck, K., \& Cihak, M. (2012). Banking competition and capital ratios.European Financial Management, 18(5), 836-866.

Sinkey, J. F. (1979). Problem and failed institutions in the commercial banking industry (pp. 34-9). Greenwich, CT: Jai Press.

Tussing, A. D. (1967). The Case for Bank Failure. The Journal of Law and Economics, 10, 129-147.

Währungsfonds, I. (2009). Global Financial Stability Report-Responding to the Financial Crisis and Measuring Systemic Risk. April, Washington, DC. 